\title{
PANDANGAN ALKITAB TENTANG PRAKTIK BISNIS DI KALANGAN HAMBA TUHAN PENUH WAKTU
}

\author{
Berniaty Palabiran \\ sttjaffray@yahoo.com \\ Daniel Ronda \\ danielronda@ymail.com
}

PENDAHULUAN

\section{Latar Belakang Masalah}

Dalam gereja ada hamba Tuhan yang mencurahkan seluruh waktu dan tenaga penuh untuk pelayanan, mereka adalah hamba Tuhan yang dikenal dengan istilah hamba Tuhan penuh waktu. Mereka dituntut untuk selalu setia dalam pelayanan, selalu siap jika ada yang membutuhkan pelayanan.

Pelayanan yang dilakukan oleh hamba Tuhan tersebut patutlah dihargai karena mereka benar-benar melakukan tugas dan tanggung jawabnya sebagai pelayan dan layak untuk mendapatkan upah yang sepantasnya. Namun, upah yang mereka terima tidak cukup untuk memenuhi kebutuhan hidupnya karena sebagian orang merasa bahwa hamba Tuhan sebaiknya hidup dalam kesederhanaan.

Gajinya sedikit di atas UMR (Upah Minimum Regional). ${ }^{1} \quad$ Sehingga tak dapat dipungkiri banyak hamba Tuhan yang menderita secara finansial, memiliki gaji pas-pasan yang mana gaji tersebut tidak cukup untuk memenuhi kebutuhan hidupnya sedangkan hamba Tuhan adalah manusia biasa yang memiliki tuntutan kebutuhan hidup bahkan ikut mengemban mandat Allah untuk bertanggung jawab terhadap isi dunia ini termasuk dirinya, keluarga dan sesamanya (Kejadian 1:28; I Timotius 5:8; Filipi 2:4). Mereka juga membutuhkan sandang, pangan dan papan yang cukup untuk kelangsungan hidup. Keadaan seperti itu membuat sebagian hamba Tuhan mencari jalan keluar sendiri dan tak ingin menyusahkan jemaat sehingga solusi yang mereka ambil adalah melakukan bisnis.

Bisnis dapat membantu hamba Tuhan untuk mencukupi kebutuhan hidupnya seperti halnya Rasul Paulus yang mencukupi kebutuhan hidupnya tanpa membebani jemaat dengan cara membuat tenda, bisnis merupakan sarana untuk menunjang pelayanan (II Korintus 11:9). Sebuah bisnis adalah lingkungan yang sangat sesuai untuk melaksanakan kebenaran Kristus. ${ }^{2}$ Wajarlah jika hamba Tuhan itu melakukan bisnis karena di dunia bisnis pun mereka dapat melayani dan membawa jiwa kepada Kristus dan mereka tidak memerlukan gaji dari gereja.

Namun seorang hamba Tuhan penuh waktu yang merangkap sebagai pebisnis memiliki masalah dilematis, seolah-olah berdiri di dua sisi, pada satu sisi, hamba Tuhan dituntut untuk penuh waktu di gereja, tetapi pada sisi yang lain, hamba Tuhan memiliki tuntutan kebutuhan hidupnya yang banyak sehingga ia harus berbisnis. Ini merupakan hal yang sulit bagi hamba Tuhan karena mau tidak mau pelayanan harus diutamakan.

Dengan melihat penjelasan tersebut di atas, membandingkan dengan pengamatan langsung di lapangan, ternyata yang penulis jumpai bahwa ada hamba Tuhan yang tidak dapat mengatur waktunya sehingga seolah-olah bisnis yang diutamakan. Kebanyakan waktu, tenaga dan pikiran lebih banyak digunakan untuk urusan bisnis daripada untuk mengurusi hal-hal yang berhubungan dengan pelayanan di gereja. Oleh karena itu, penulis tertarik untuk mengangkatnya dalam sebuah karya ilmiah yang berjudul "Pandangan Alkitab Tentang Praktik Bisnis di Kalangan Hamba Tuhan yang Penuh Waktu."

\section{Pokok Masalah}

Berdasarkan latar belakang yang telah diuraikan, maka penulis mengangkat pokok masalah, sebagai berikut:

Pertama, faktor-faktor apakah yang menyebabkan hamba Tuhan melakukan bisnis? Kedua, apakah prinsip-prinsip hamba Tuhan melakukan bisnis? Ketiga, apakah bahaya menjadi hamba Tuhan yang berbisnis?

\footnotetext{
${ }^{1}$ Abednego, "Honor Gembala," Sahabat Gembala, No. 411 (Juli 2009), 9.

${ }^{2}$ Larry Burket, Mengatur Keuangan dengan Bijak (Bandung: Yayasan Kalam Hidup), 178.
} 
Tujuan Penulisan hal, yaitu:

Adapun tujuan yang hendak dicapai dalam penulisan ini berdasarkan atas beberapa

Pertama, untuk mengetahui faktor-faktor yang dapat menyebabkan hamba Tuhan melakukan praktik bisnis.

Kedua, untuk memberi masukan bagi hamba Tuhan yang berbisnis agar dapat menjalankan bisnisnya dengan menerapkan prinsip-prinsip yang benar.

Ketiga, untuk mengetahui bahaya-bahaya menjadi hamba Tuhan berbisnis.

\section{Manfaat Penulisan} berikut:

Adapun yang menjadi manfaat dari penulisan karya ilmiah ini adalah sebagai

Pertama, sebagai bahan kajian untuk didiskusikan, sehingga mendapat pemahaman yang benar berdasarkan Alkitab, sehingga sebagai hamba Tuhan yang melakukan praktik bisnis menggunakan materi mereka untuk kemuliaan Tuhan.

Kedua, sebagai sarana untuk memberi masukan, motivasi, dorongan bagi hamba Tuhan untuk melakukan praktik bisnis dengan mengikuti prinsip-prinsip Alkitabiah.

Ketiga, untuk memenuhi tuntutan akademik guna memenuhi salah satu persyaratan dalam jenjang pendidikan program strata satu di Sekolah Tinggi Theologia Jaffray Makassar.

\section{Batasan Penulisan}

Mengingat masalah sangat luas, maka penulis hanya membatasi diri dan memfokuskan pada suatu topik yang sangat menarik, yaitu: "Pandangan Alkitab Tentang Praktik Bisnis di Kalangan Hamba Tuhan yang Penuh Waktu."

\section{PANDANGAN TEOLOGIS TENTANG BISNIS}

\section{Pandangan Alkitab}

Dalam Alkitab kita tidak menemukan satu kata yang dengan jelas memaparkan tentang praktek bisnis di kalangan hamba Tuhan penuh waktu tetapi dalam Alkitab dapat ditemukan bentuk organisasi bisnis yang masih dalam bentuk sederhana baik dalam Perjanjian Lama maupun Perjanjian Baru.

\section{Menurut Perjanjian Lama}

Dalam kitab Perjanjian Lama hal berusaha sangat ditekankan oleh Alkitab karena merupakan tugas yang diberikan oleh Allah kepada manusia. Seperti dikatakan dalam kitab Kejadian 1:26 bahwa bumi ini diciptakan Tuhan untuk dimanfaatkan oleh manusia dan berbisnis merupakan salah satu cara untuk melaksanakan kehendak Allah untuk menguasai, memenuhi dan menaklukkan bumi dengan penuh tanggung jawab. Allah telah mendelegasikan wewenang kepada Adam supaya dapat menjalankan tugas dan fungsinya. Sebenarnya sudah terjadi transaksi sederhana antara Tuhan dan manusia. Hal ini berarti bahwa bisnis itu muncul sejak manusia ada di muka bumi. ${ }^{3}$

Pada zaman Nuh, manusia mulai berusaha membuat bahtera. Ordernya datang dari Tuhan dan digunakan oleh manusia yang ingin diselamatkan oleh Allah dari air bah (Kejadian 6:14). Setelah peristiwa air bah, Allah memberkati bumi lagi dan ini memberikan gambaran tentang perkembangan bisnis yang kelihatan dan bisa dicapai oleh anak-anak manusia sampai saat ini. ${ }^{4}$

Usaha pertanian dan perkebunan yang sekarang dikenal sebagai agrobisnis. Tuhan menunjukkan perhatian-Nya dalam agrobisnis ketika Ia berjanji: "Selama bumi masih ada, takkan berhenti-henti musim menabur dan menuai."

Bisnis perburuan dipelopori oleh Nimrod, seorang pemburu yang gagah perkasa di hadapan Tuhan (Kejadian 10:9). Peristiwa di Babel (Kejadian 11:8-9) ternyata tumbuh banyak cikal bakal bisnis manusia seperti membuat batu bata, bisnis bahasa, keramik. ${ }^{6}$

Sebagian besar tulisan Musa dalam Perjanjian Lama terdiri atas perintah-perintah Tuhan mengenai usaha pertanian (Imamat 25:3-4). Tuhan juga terlibat dalam bisnis real estate (tanah dan rumah) dan cara mengadakan transaksi dalam bisnis tersebut (Imamat 25:10-25; Ulangan 19:14;27:17). ${ }^{7}$

\footnotetext{
${ }^{3}$ Mahli Sembiring, Kiat Bisnis Kristen (Jakarta: Pustaka Sinar Harapan, 1997), 27.

${ }^{4}$ Ibid, 30.

5"Hamba Tuhan Berbisnis,"diakses 29 April 2010; tersedia di http://johnlock88.blogspot.com/2010/03/hamba-tuhan-dan-bisnis.

${ }^{6}$ Mahli Sembiring, Kiat Bisnis Kristen (Jakarta: Pustaka Sinar Harapan, 1997), 31

7"Hamba Tuhan Berbisnis,"diakses 29 April 2010; tersedia di http://johnlock88.blogspot.com/2010/03/hamba-tuhan-dan-bisnis.
} 
Perlu diketahui bahwa dalam Perjanjian Lama banyak kita jumpai masyarakat Yahudi yang melakukan bisnis yaitu usaha dagangan misalnya tukang perak atau tukang tenun. Orang Yahudi melakukan banyak kegiatan bisnis karena dalam Perjanjian Lama bekerja itu sangat dihormati. ${ }^{8}$ William Barclay mencatat:

bagi orang Yahudi bekerja adalah kehidupan. Orang Yahudi mengenal ungkapan "orang yang tidak mengajar anak lelakinya berusaha, mengajarnya mencuri." Seorang rabi Yahudi sama kedudukannya dengan seorang dosen atau profesor di perguruan tinggi, tetapi menurut hukum Yahudi ia tak boleh menerima satu sen pun dari tugas mengajarnya; ia harus menguasai suatu bidang usaha yang dilakukannya dengan tangannya dan dengan demikian ia memenuhi kebutuhannya sendiri. Karena itu ada rabi yang menjadi tukang jahit, tukang sepatu, tukang cukur, atau tukang roti dan bahkan pula menjadi aktor. Bekerja bagi seorang Yahudi adalah kehidupan. ${ }^{9}$

Jadi, orang Yahudi khususnya rabi mereka juga mencari penghasilan sendiri salah satu cara adalah berbisnis. Orang Yahudi sangat menghargai keahlian dan keterampilan Dalam Perjanjian Lama kita jumpai hamba Tuhan yang melakukan bentuk bisnis misalnya pengusaha di bidang peternakan, Abraham, Ayub, Lot, Habel, Musa, Jitro, dan Daud.

Ketika bangsa Israel menduduki tanah Kanaan yang merupakan daerah yang subur dan produktif yang melimpah susu dan madu (Keluaran 3:8; Ulangan 26:8), orang Israel mulai mengusahakan daerah itu untuk memenuhi kebutuhan ekonomi mereka. Kanaan merupakan tempat perdagangan yang disukai karena letaknya tepat pada jalur perdagangan yang utama. Banyak bangsa membarter hasil-hasil dari tanah Kanaan misalnya minyak zaitun ditukarkan dengan hasil dari Mesir. Yehezkiel menulis, "Yuda dan tanah Israel berdagang dengan engkau; mereka menukarkan gandum dari Minit, mur, madu, minyak dan balsam ganti barang-barang daganganmu" (Yehezkiel 27:17). ${ }^{10}$

Jadi, kita dapat melihat bahwa perekonomian di Israel sangat maju dan banyak membuka peluang bisnis pada masa itu. Bahkan kitab Torat menempatkan semua kegiatan ekonomi (bisnis) dalam kerangka hubungan perjanjian dengan bangsa Israel. ${ }^{11}$

Dalam kitab-kitab sejarah, dapat kita melihat bahwa bisnis dalam bidang perdagangan sangat maju bahkan Salomo yang adalah raja juga terlibat dalam usaha dagang. Dalam 1 Raja-raja 4:22-24 dengan jelas memperlihatkan daerah kekuasaan Salomo yang di dalamnya terdapat pertaian dan peternakan. Salomo mengimpor bahan untuk bait suci dari negeri-negeri tetangga (1 Raja-raja 9:15). ${ }^{12}$

Yehezkiel seorang nabi dalam kitabnya memberi tahu banyak hal mengenai cara-cara berdagang orang Fenisia (Yehezkiel 27:3). Barang-barang yang diperdagangkan waktu itu ialah emas, perak, tembaga, timah, besi, gading, kaca, kayu, bitumen, rami, kapas, dan wol. $^{13}$

Zaman Perjanjian Lama banyak dijumpai bisnis misalnya daerah Palestina yang kendati negeri miskin dapat menjadi kaya oleh perdagangan. Dalam Yehezkiel 27:12-25 menggambarkan kegiatan perdagangan dunia melalui jalur lintas daerah Palestina. Sumbangan utama Palestina untuk perdagangan pada zaman Perjanjian Lama ialah hasilhasil pertanian dan logam. Fenisia adalah suatu Negara industri yang harus mengimpor makanan. Israel memasok gandum, minyak dan anggur untuk Fenisia. ${ }^{14}$

Firman Tuhan sangat menekankan kejujuran dalam berbisnis seperti dikatakan dalam Imamat 25:14, "Apabila kamu menjual sesuatu kepada sesamamu atau membeli dari padanya, janganlah kamu merugikan satu sama lain”. Namun kenyataannya berbeda, salah satu masalah yang dihadapi dunia perdagangan pada masa Perjanjian Lama adalah tidak ada kejujuran dalam kehidupan sehari-hari misalnya menggunakan timbangan dan ukuran palsu dalam berdagang (Imamat 19:36). Bukan hanya orang awam namun para nabi juga menunjukkan praktek-praktek penipuan dalam perdagangan. ${ }^{15}$ Ini merupakan hal yang tidak diinginkan oleh Tuhan dan menyebabkan bisnis itu seolah-olah terpisah dari urusan Tuhan karena mereka hanya memikirkan kesenangan belaka.

Perlu dipahami bahwa walaupun ada bentuk-bentuk bisnis yang ditemui dalam masa Perjanjian Lama tetapi tidak ada satu pun contoh konkret yang membahas tentang hamba Tuhan penuh waktu yang melakukan praktik bisnis karena pada masa Perjanjian Lama seorang hamba Tuhan atau seorang imam kebutuhan hidupnya itu disokong oleh persembahan bangsa Israel yaitu kedua belas suku (Bilangan 18:8-24), sehingga tidak ada alasan bagi mereka untuk berbisnis. Demikian pula dengan kaum Lewi yang walaupun tidak memiliki pusaka tetapi tetap dapat mencukupi kebutuhannya dengan disokong oleh

${ }^{8}$ Jerry dan Mary White, Bekerja (Jakarta: BPK Gunung Mulia, 1980), 16

${ }^{9}$ Ibid.

${ }^{10}$ J.l. Packer, Merrill C. Tenney dkk, Ensiklopedia Fakta Alkitab Bible almanac-1 (Malang: Yayasan Penerbit Gandum Mas, 2001), 559-561.

${ }^{11}$ http://psbrahmana.blogspot.com/2009/09/dapatkah-bisnis-dilakukan-berdasarkan 06.html. 06 Mei 2010

${ }^{12}$ J.1. Packer, Merrill C. Tenney dkk, Ensiklopedia Fakta Alkitab Bible almanac-1 (Malang: Yayasan Penerbit Gandum Mas, 2001), 556

${ }^{13} \mathrm{Ibid}, 569$.

${ }^{14}$ Ibid, 567

${ }^{15}$ Ibid, 563 
persembahan bangsa Israel (Bilangan 18:8-24), sehingga ia tidak perlu disibukkan oleh pikiran bagaimana memenuhi kebutuhan dasariah.

Berdasarkan penjelasan di atas dapat disimpulkan bahwa bisnis itu muncul sejak manusia ada di muka bumi dan Tuhan terlibat di dalam bisnis. Walaupun pada masa itu tidak secara jelas ditemukan imam yang berbisnis tetapi bentuk bisnis dapat ditemukan dalam kehidupan orang pilihan Tuhan yang mana mereka juga adalah hamba Tuhan. Bagi kaum Lewi pada masa Perjanjian Lama bisnis tidak diperbolehkan karena mereka adalah orang yang hanya dikhususkan untuk pelayanan di bait Allah dan kebutuhan mereka telah disokong oleh persembahan bangsa Israel. Pada masa Perjanjian Lama hidup yang berkelimpahan diartikan sebagai hidup yang diberkati oleh Allah dan hal itu nampak dalam pola hidup dan kerja orang-orang yang dipilih-Nya misalnya Abraham, Nuh, Daniel, Hanaya yang memperlihatkan bahwa mereka bukanlah orang yang hidup dalam kemiskinan dan hanya berperan dalam bidang rohani tetapi juga ikut berperan dalam bidang politik, sosial dan ekonomi.

\section{Menurut Perjanjian Baru}

Dunia bisnis pada waktu itu berpengaruh terhadap penyebaran Injil. Orang-orang Kristen mula-mula menjadikan dunia usaha sebagai titik penting dari pelayanan mereka. Ketika mereka menjalankan bisnis, ada sesuatu yang natural bagi mereka untuk memberitakan Injil kepada orang-orang yang mereka temui. ${ }^{16}$

Sepanjang zaman Perjanjian Baru perdagangan dikuasai oleh Roma dan Italia dan kota pusat perdagangan dan perniagaan berada di kota Tiatira. ${ }^{17}$ Peranan perindustrian pada waktu itu sangat berpengaruh di mana mulai muncul pabrik-pabrik yang merupakan perusahaan pribadi. Pertukangan dan industri, baik industri kecil di rumah maupun industri lebih besar terdapat di kota-kota. ${ }^{18}$

Galilea terdapat industri perikanan, diorganisasi dalam koperasi-koperasi oleh para pemilik dan pekerja (Markus 1:12) ${ }^{19}$

Dalam kitab Injil, hampir seperempat perumpamaan Tuhan Yesus yang berkaitan dengan keadaan-keadaan bisnis misalnya dalam kitab Injil Matius 13:45. Bahkan Yesus sendiri memulai hidup-Nya dan kurang lebih 18 tahun ia menghabiskan hidupnya sebagai seorang pengusaha (tukang kayu).

Kisah Para Rasul 18:3 disebutkan bahwa Paulus yang adalah hamba Tuhan menghidupi dirinya dengan usaha kemah. Ia menghidupi dirinya sendiri bahkan membantu jemaat yang membutuhkannya. Sebagai seorang hamba Tuhan yang merangkap sebagai pebisnis, Paulus dapat menyeimbangkan antara pelayanan dan bisnisnya. Melalui profesinya, ia membiayai sendiri perjalanan pelayanannya karena pada masa Perjanjian Baru tidak seperti masa Perjanjian Lama yang mana hidup seorang imam disokong oleh persembahan bangsa Israel sehingga Paulus mengambil profesi sebagai tukang kemah.

Selain Paulus, ada juga Lidia yang adalah hamba Tuhan dari kota Tiatira yang menjual kain ungu (Kisah Para Rasul 16:4). Begitu pula dengan Akwilla dan Priskilla mereka adalah pengusaha pembuat tenda yang mana melalui mereka terjadi kegerakan transformasi di Efesus. Ini menunjukkan bahwa hamba Tuhan pada masa itu diizinkan Tuhan memimpin dunia usaha untuk tujuan yang khusus yaitu penyebaran Injil.

Rasul Yakobus menyetujui kegiatan orang-orang Kristen yang berdagang untuk memperoleh keuntungan; namun ia mengingatkan mereka bahwa yang terutama harus mereka perhatikan adalah kehendak Allah. Yakobus 4: 12-16 jelas mengatakan siapa saja yang mengabaikan hal ini adalah sombong dan angkuh. ${ }^{20}$

Di dalam semua urusan bisnis, Tuhan mengajar umatNya agar bersikap jujur sepenuhnya, dan juga bermurah hati. "Suatu takaran yang baik, yang dipadatkan, yang digoncang dan yang tumpah ke luar" adalah cara Allah berbisnis (lihat Lukas 6:38).

Murid-murid Yesus yang pertama adalah nelayan (Matius 4:18), yang sesudah Yesus wafat kembali ke pekerjaan semula (Yohanes 21:3). ${ }^{21}$ Seperti Petrus yang menjadi nelayan, mereka berkecimpung di dunia bisnis sebelum mereka menjadi pengikut Yesus kemudian setelah Yesus telah terangkat ke sorga ia kembali meneruskan pekerjaannya sebagai nelayan.

Jadi, Alkitab Perjanjian Lama dan Perjanjian Baru tidak pernah melarang hamba Tuhan penuh waktu untuk melakukan bisnis asalkan dilakukan sesuai kebenaran firman Tuhan seperti yang dilakukan oleh Paulus yang menjual tenda demi pelayanan dan kebutuhan hidupnya. Bahkan kisah Tuhan Yesus dan Paulus menjadi teladan kepada manusia bahwa hidup itu tidak lepas dari tanggung jawab untuk bekerja demi kelangsungan hidup dari kehidupan yang Dia berikan.

96.

${ }^{16}$ Niko Njotorahardjo dan Iman Santoso, Transformation journey (Yogyakarta: Penerbit Andi, 2007),

${ }^{17}$ Ensiklopedia Alkitab Masa Kini (Jakarta: Yayasan Komunikasi Bina Kasih, 1992), 222.

${ }^{18} \mathrm{C}$. Groenen OFM, Pengantar ke dalam Perjanjian Baru (Yogyakarta: Kanisius, 1984), 58

${ }^{19}$ Ensiklopedia Perjanjian Baru (Yogyakarta: Kanisius, 1990), 57.

${ }^{20}$ Ibid, 681 .

${ }^{21}$ Ensiklopedia Perjanjian Baru (Yogyakarta: Kanisius, 1990), 58. 


\section{Menurut Gereja-Gereja Saat Ini}

Dalam konsep pandangan gereja saat ini, penulis memaparkan dari tiga aliran gereja saja mengenai praktek bisnis di kalangan hamba Tuhan penuh waktu, yakni:

\section{Gereja Injili}

Aliran gereja Injili terbagi dua yaitu ada yang mengizinkan hamba Tuhan penuh waktu untuk berbisnis dan ada juga yang tidak. ${ }^{22}$ Berbisnis bukanlah menjadi masalah di kalangan hamba Tuhan penuh waktu asalkan pelayanan tetap diutamakan, seperti gereja Injili yang terletak dipelosok-pelosok yang jemaatnya berpenghasilan sedikit sehingga gembala tidak ingin merepotkan jemaat dan mencukupi kebutuhan sendiri melalui bisnis, contohnya gembala sidang GKII Rehobot di daerah Mamuju yang berbisnis di bagian pertanian.

Jadi, tidak semua gereja Injili mengizinkan hamba Tuhan penuh waktu untuk berbisnis, semuanya itu tergantung sinode masing-masing.

Gereja Kharismatik

Aliran gereja Kharismatik tidak memiliki batasan yang tegas untuk hamba Tuhan penuh waktu yang berbisnis karena mereka melakukan itu semuanya itu untuk menunjang pelayanan serta membantu jemaatnya. ${ }^{23}$ Hamba Tuhan boleh berbisnis asalkan mereka menggunakan itu untuk kemuliaan Tuhan karena bisnis itu milik Tuhan serta dapat digunakan untuk membantu jemaat yang kekurangan. ${ }^{24}$

Walaupun gereja Kharismatik tidak memiliki batasan yang tegas tetapi tidak semua gereja Kharismatik mengizinkan hamba Tuhan itu untuk berbisnis semua itu tergantung dari sinode masing-masing.

\section{Gereja Protestan}

Aliran gereja protestan seperti Gereja Toraja, HKBP, GPIB tidak mengizinkan hamba Tuhan penuh waktu untuk berbisnis karena bentuk administrasinya berasal dari pusat sehingga gajinya dianggap cukup untuk memenuhi kebutuhan hidupnya dan harus fokus untuk pelayanan saja. ${ }^{25}$

Jadi, sinode gereja protestan tidak mengizinkan hamba Tuhan penuh waktu untuk berbisnis karena gaji mereka telah ditetapkan dan itu dianggap cukup untuk memenuhi kebutuhan hidupnya.

Jadi, pada dasarnya secara teologis seorang hamba Tuhan penuh waktu boleh berbisnis walaupun dalam konsep Perjanjian Lama jelas bahwa pelayan Tuhan yakni kaum Lewi tidak melakukan bisnis karena kebutuhan dasariahnya telah disokong oleh bangsa Israel pada masa itu sehingga tidak ada alasan untuk berbisnis. Namun, jika direlevansikan dengan zaman ini maka kaum Lewi boleh berbisnis karena masa ini tidak sama dengan masa Perjanjian Lama kecuali jemaatnya mampu untuk memenuhi kebutuhan dasariahnya karena hal ini sangat berpotensi untuk mengganggu efisien dan efektivitas pelayanannya. ${ }^{26}$ Ini berarti bahwa jemaat perlu memperhatikan kebutuhan hamba Tuhan agar mereka dapat fokus untuk melayani tanpa memikirkan kebutuhan dasariahnya. Jadi, perlu ada kesadaran dari jemaat untuk memperhatikan kebutuhan hamba Tuhan agar mereka tidak mencari usaha sampingan dan fokus pada pelayanan saja. Hamba Tuhan harus mematuhi sinode atau tata gereja yang berlaku di gereja tempat ia melayani. Jika dalam tata gereja tempat ia melayani diizinkan untuk berbisnis maka tidak ada salahnya tetapi jika sebaliknya tidak diperbolehkan maka hamba Tuhan harus menaatinya agar tidak menjadi batu sandungan dalam pelayanannya.

\section{TINJAUAN TERHADAP HAMBA TUHAN PENUH WAKTU YANG BERBISNIS}

Dalam bab ini penulis memaparkan tinjauan terhadap hamba Tuhan penuh waktu yang memiliki bisnis antara lain:

\section{Faktor-Faktor Penyebab Hamba Tuhan Melakukan Bisnis}

Penulis menemukan ada dua faktor yang menyebabkan hamba Tuhan penuh waktu melakukan praktik bisnis, yaitu: Pertama, gaji yang diterima oleh hamba Tuhan tersebut tidak cukup untuk memenuhi kebutuhan hidupnya sehingga menyebabkan hamba Tuhan menderita secara finansial. ${ }^{27}$ Hal ini menyebabkan beberapa hamba Tuhan untuk melakukan praktik bisnis dengan alasan tidak ingin merepotkan jemaat. Hamba Tuhan yang tinggal di daerah terpencil malah tidak digaji oleh karena jemaat juga hidup dalam serba kekurangan. Jangankan menggaji pendeta, kebutuhan dasariah mereka untuk

\footnotetext{
${ }^{22}$ Daniel Ronda, Wawancara Oleh Penulis, Makassar, Sulawesi Selatan, 12 Juli 2010 ${ }^{23}$ Ibid.

${ }^{24}$ Benyamin Tombe, Wawancara Oleh Penulis, Makassar, Sulawesi Selatan, 28 Mei 2010.

${ }^{25}$ Zeeman Doalangi, Percakapan telepon dengan penulis, 27 Juli 2010.

${ }^{26}$ E. B. Surbakti, “Dari Mana Penghasilan Pendeta?,"Sahabat Gembala, No.4ll (Juli 2009), 19.

${ }^{27}$ Abednego, "Honor Gembala,"Sahabat Gembala, No 411 (Juli 2009), 9.
} 
sekedar bertahan hidup pas-pasan. ${ }^{28}$ Oleh karena itu, hamba Tuhan harus berhikmat agar tetap dapat bertahan hidup. Kedua, mengembangkan potensi dalam diri mereka yaitu bakat untuk berbisnis. ${ }^{29}$ Ada hamba Tuhan yang memiliki bakat untuk berbisnis sehingga menjadikan bisnis itu sebagai usaha sampingan yang hasilnya digunakan untuk kepentingan pelayanan. Berdasarkan penjelasan di atas dapat disimpulkan bahwa faktor yang menyebabkan hamba Tuhan melakukan praktik bisnis karena gajinya yang tidak memadai dan adanya keinginan untuk mengembangkan bakat yang ia miliki yang mana ia gunakan untuk kemuliaan Tuhan.

\section{Prinsip Hamba Tuhan yang Berbisnis}

Berdasarkan prinsip bisnis umum dan kajian Alkitab maka perlu motivasi yang jelas bahwa hamba Tuhan penuh waktu yang memiliki pekerjaan sampingan sebagai pebisnis bukanlah sesuatu yang salah karena mereka adalah orang-orang yang memiliki dan mau mengembangkan potensi dalam diri mereka asalkan melaksanakan bisnis itu dengan benar sesuai kehendak Tuhan dan memuliakan Tuhan. Jadi, penulis menemukan bahwa menjadi hamba Tuhan penuh waktu yang berbisnis tidak ada masalah yang penting memiliki prinsip-prinsip penting sebagai berikut:

\section{Hamba Tuhan Penuh Waktu yang Ideal}

Hamba Tuhan penuh waktu yang ideal adalah hamba Tuhan yang tidak lari dari panggilannya dan yang tidak menyembunyikan potensi yang mereka miliki justru mereka mengembangkannya karena tidak ingin membebani jemaat. ${ }^{30}$ Melalui bisnis, mereka dapat memenuhi kebutuhan hidupnya sendiri dan membantu sesamanya.

Kepercayaan yang Tuhan berikan dalam bisnis itu harus digunakan sebaik-baiknya untuk membantu jemaat atau sesama yang kesulitan ekonomi yang dapat dijangkau misalnya mempekerjakan dia sesuai dengan potensinya. ${ }^{31}$ Akan tetapi ini bukan hal yang mudah karena hamba Tuhan harus menyadari bahwa tugas dan tanggung jawab yang utama adalah melayani jemaat.

Namun, ini bukan berarti menjalankan bisnis atau usahanya dengan asal-asalan karena merupakan usaha sampingan melainkan hamba Tuhan tersebut haruslah profesional dalam menjalankan bisnisnya karena bisnis adalah milik Tuhan. Elsen Tan menjelaskan,

Profesi itu berasal dari kata "profesus" dari bahasa latin yang berarti "declare publicy", pernyataan yang dilakukan di hadapan orang banyak dan melibatkan Tuhan sebagai saksi. Dengan demikian professional dimaknai sebagai orang yang melakukan keahliannya dengan komitmen moral kepada Tuhan untuk melakukan yang terbaik bagi sesama dan dapat mendatangkan nafkah hidup dan profesionalisme mengutamakan perihal komitmen pelayanan, bukan seperangkat kompetensi. ${ }^{32}$

Ini berarti bahwa hamba Tuhan penuh waktu yang berbisnis haruslah memiliki komitmen moral yang kuat atau dengan kata lain bahwa karakternya sebagai hamba Tuhan harus nampak dalam lingkungan bisnisnya.

Seperti yang dikemukakan oleh Pdt. Hendrik bahwa dalam menjalankan usaha haruslah memiliki hati hamba yaitu ada penundukan diri bahwa bisnis itu adalah milik Tuhan dan kita hanya pengelolah saja dan keberhasilan itu karena anugerah Tuhan saja.

Walaupun harus professional dalam bisnis, seorang hamba Tuhan yang haruslah dapat mengatur waktu antara bisnis dan pelayanannya, jangan sampai ia lebih banyak sibuk mengurusi bisnis daripada pelayanannya. Cara yang seharusnya ditempuh hamba Tuhan penuh waktu yang berbisnis ialah harus pintar menggunakan waktu yang ada dengan berkualitas sehingga menghasilkan hal-hal yang berkualitas baik dalam bisnis maupun pelayanan. ${ }^{33}$ Di mana hamba Tuhan seharusnya menunjuk seseorang sebagai orang kepercayaannya untuk membantunya dalam urusan bisnis agar pelayanan tidak terbengkalai.

Jemaat memang menuntut hamba Tuhan harus penuh waktu dalam pelayanan karena itu memang tugasnya dan hanya dengan menggunakan waktu yang berkualitas serta menyeimbangkan keduanya maka hamba Tuhan tersebut dapat melaksanakan tugas pelayananya. Jemaat harus dilatih untuk menjadi jemaat yang mandiri dan tidak manja maksudnya jemaat diajar untuk dapat mengatasi masalahnya yang masih bisa dia atasi sendiri sesuai ajaran firman Tuhan dan ini bukan berarti menelantarkan jemaat. ${ }^{34}$ Sebagai jemaat yang hamba Tuhannya memiliki bisnis maka jemaat harus peduli dan mendukung keputusannya untuk berbisnis karena mereka melakukan semua itu untuk memenuhi kebutuhan hidupnya dan membantu pelayanan asalkan tetap memprioritaskan pelayanan. 35

\footnotetext{
${ }^{28} \mathrm{Ibid}, 20$.

${ }^{29}$ Hendrik Gomulyo, Wawancara Oleh Penulis, Makassar, Sulawesi Selatan, 16 Mei 2010.

${ }^{30}$ Bunga, Wawancara Oleh Penulis, Mamasa, Sulawesi Barat, 06 Juni 2010.

${ }^{31}$ Benyamin Tombe, Wawancara Oleh Penulis, Makassar, Sulawesi Selatan, 28 Mei 2010.

${ }^{32}$ Elsan Tan, Siapa Bilang Pengusaha Bukan Hamba Tuhan (Light Publishing, 2010), 50.

${ }^{33}$ Hendrik Gomulyo, Wawancara Oleh Penulis, Makassar, Sulawesi Selatan, 16 Mei 2010

${ }^{34}$ Benyamin Tombe, Wawancara Oleh Penulis, Makassar, Sulawesi Selatan, 28 Mei 2010.

${ }^{35}$ Enos, Wawancara Oleh Penulis, Makassar, Sulawesi Selatan, 13 Juli 2010.
} 
Jadi, dalam menjalankan pelayanan dan bisnis harus ada keseimbangan, jangan pernah mengganggap bisnis itu urusan duniawi karena Tuhan tidak pernah membedakan tetapi semuanya itu adalah pemberian Tuhan karena Tuhan ingin agar kerajaanNya hadir secara mutlak disetiap aspek kehidupan manusia termasuk bisnis namun tetap memprioritaskan pelayanan sebagai yang utama. Hamba Tuhan harus melihat bisnis sebagai pelayanan dan melakukan semuanya itu untuk kemuliaan Tuhan karena bisnis itu adalah milik Tuhan dan kita hanya pengelola saja. ${ }^{36}$ Idealnya seperti Paulus dapat melaksanakan pelayanan dan pekerjaannya secara seimbang sehingga tidak ada yang terbengkalai, ia bekerja membuat tenda untuk memenuhi kebutuhan pribadinya bahkan separuh dari penghasilannya itu digunakan untuk membantu pelayanan pada masanya dan Paulus dapat membagi waktunya dengan baik.

\section{Melakukan Kegiatan Rohani}

Menyadari bahwa bisnis adalah milik Tuhan maka dalam usaha harus ada hubungan yang intim dengan Tuhan. Pdt. Benyamin Tombe mengutarakan bahwa bisnis itu sama halnya dengan gereja karena sama-sama konsep kerajaan Allah sehingga dalam usaha atau perusahaan yang dikelolah perlu adanya hubungan yang akrab dengan sang pemilik itu sendiri dengan jalan mengadakan berbagai kegiatan rohani bersama karyawannya. Kegiatan rohani tersebut dapat ditempuh melalui beberapa cara antara lain:

Membentuk Persekutuan Kristen. Persekutuan seperti ini dimaksudkan untuk memupuk kerohanian anak-anak Tuhan agar bisa bertumbuh dewasa dalam Tuhan. Setiap hamba Tuhan penuh waktu yang berbisnis harus memberikan pengarahan rohani bagi karyawannya.

Kata-kata yang berkaitan dengan ibadah menurut Kamus Yunani antara lain: (1).


menelungkupkan diri sebagai penghormatan di mana orang yang beribadah memandang objek yang disembah layak untuk menerima apa yang sedang dipersembahkannya. Bahkan dalam bahasa Inggris kata "Worship" yang berarti memberikan penghormatan kepada objek yang disembah. Sedangkan kata yang kedua menurut Kamus Yunani ialah "Latreo" $(\Lambda \alpha \tau \rho \varepsilon \omega)$. Kata ini mengandung arti bahwa ibadah merupakan pelayanan iman. Seluruh kehidupan orang percaya harus menjadi ibadah pelayanan (Roma 12:1). ${ }^{37}$

Ibadah dalam Perjanjian Lama merupakan suatu keharusan bagi umat Tuhan. Dalam Keluaran 23:25, Allah berfirman, "Kamu harus beribadah kepada Tuhan Allahmu maka Ia akan memberikan roti makananmu dan air minumanmu dan Aku akan menjauhkan penyakit dari tengah-tengahmu." Demikian pula dalam Perjanjian Baru, kebiasaan beribadah harus ditingkatkan. Dalam I Timotius 4:7-8 berbunyi,"latihlah dirimu beribadah. Latihan badani terbatas gunanya, tetapi ibadah itu berguna dalam segala hal, karena mengandung janji, baik untuk hidup ini maupun untuk hidup yang akan datang.

Berdasarkan beberapa pengertian ibadah tersebut di atas maka dapat disimpulkan bahwa ibadah yang dimaksudkan ialah bersekutu untuk memuliakan nama Tuhan dengan puji-pujian dan mendengar firman Tuhan yang dibawakan oleh hamba Tuhan. Dalam acara ibadah, hamba Tuhan harus mendorong karyawannya untuk menyampaikan kesaksiannya tentang pengalaman-pengalaman yang ia alami dalam hidupnya atau menyampaikan bagaimana cinta kasih Tuhan yang berlaku dalam hidupnya di mana ibadah ini bertujuan untuk menguatkan, menumbuhkan iman setiap orang yang menghadiri ibadah tersebut serta dapat berhati-hati dalam melakukan bisnis agar sungguh-sungguh berdasarkan prinsip firman Tuhan. Jadi, sepanjang hari kerja maka harus dipersiapkan hari dan jam yang dikhususkan untuk melakukan ibadah. Selain ibadah bersama karyawan, ada baiknya hamba Tuhan tersebut atau karyawannya mengikuti komunitas bisnis Kristen atau organisasi pengusaha Kristen misalnya komunitas KBC (Kingdom Business Community), BOM (Business and Office Ministry), BBC (Bethany Business Community). Selain Ibadah, cara yang kedua ialah membentuk persekutuan

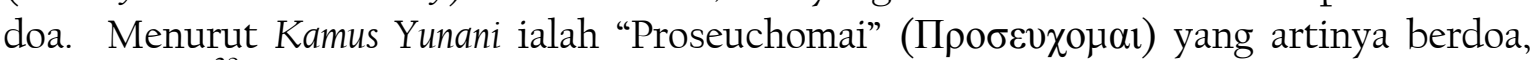
sembayang." ${ }^{38}$ Sedangkan menurut Ensiklopedia Alkitab Masa Kini doa ialah:

Kebaktian mencakup segala sikap roh manusia dalam pendekatannya kepada Allah. Orang Kristen berbakti kepada Allah, jika ia memuji, mengagungkan dan mengajukan permohonan kepada Allah dalam doa. Doa sebagai perbuatan tertinggi yang dapat dilakukan oleh roh manusia, dapat juga dipandang sebagai persekutuan dengan Allah, selama penekanannya diberikan kepada Allah karena Allah telah menyentuh rohnya. Dalam Alkitab berdoa bukanlah suatu tanggapan biasa dari manusia, tetapi suatu tanggapan yang sungguh-sunggih dari manusia. ${ }^{39}$

${ }^{36}$ Benyamin Tombe, Wawancara Oleh Penulis, Makassar, Sulawesi Selatan, 28 Mei 2010.

${ }^{37}$ Jeremie Lie, Penulisan: Peranan Seorang Pengusaha Kristen dalam Pelayanan Pekerjaan Tuhan (Makassar: STTJ, 2001), 35

${ }^{38} \mathrm{Ibid}, 36$

${ }^{39}$ Ensiklopedia Alkitab Masa Kini, Jilid I,(Jakarta: Yayasan Komunikasi Bina Kasih/OMF, 1992 ), s.v. 
Kamus Besar Bahasa Indonesia memberikan defenisi tentang doa sebagai "permohonan (harapan, permintaan, pujian) kepada Tuhan." ${ }^{40}$

Doa berarti komunikasi, melalui jasa darah Yesus Kristus dan atas dasar pekerjaan penebusan-Nya, antara manusia dan pribadi Allah yang kekal dan tak terbatas, yang adalah Bapa daripada Tuhan kita Yesus Kristus. ${ }^{41}$

Jadi, penulis dapat menyimpulkan bahwa doa ialah ungkapan isi hati manusia tentang segala pergumulan hidupnya yang disampaikan dengan permohonan, ucapan syukur, dengan penuh pengharapan kepada Allah melalui perantara Yesus Kristus. Hamba Tuhan penuh waktu patut mengarahkan karyawannya agar tidak salah dalam berdoa. Firman Tuhan mengajarkan kita untuk berdoa yang benar dan memiliki iman (Yakobus $5: 16)$.

Berdasarkan firman Tuhan di atas maka hal yang perlu diperhatikan dalam berdoa ialah: Pertama memanjatkan doa dengan benar dihadapan Tuhan. Menurut Kamus Bahasa Indonesia, kata benar memiliki tiga pengertian yakni; (1). Kesungguhan hati, (2). Hal yang sesungguhnya, (3). Sesuatu yang benar menurut Agama.

Jadi, berdoa yang benar adalah berdoa dengan penuh kesungguhan hati, kejujuran dan kebenaran di hadapan Tuhan. Kedua, berdoa dengan iman. Kamus Besar Bahasa Indonesia memberikan defenisi tentang iman sebagai " suatu kepercayaan yang berkenaan dengan agama atau keyakinan kepada Allah, nabi, kitab, dan sebagainya." ${ }^{22}$ Selanjutnya Harold mengatakan, "iman adalah kepercayaan yang mutlak kepada sesuatu yang dianggap benar, artinya iman melibatkan unsur kehendak dan unsur perasaan atau emosi. Emosi dan kehendak semua bekerja sama dan bersatu dalam mempraktekkan iman". ${ }^{3} \mathrm{~J}$. Wesley Brill menjelaskan:

Iman di dalam doa ialah pengharapan yang teguh atau keyakinan bahwa kita akan menerima apa yang kita minta, tanpa keragu-raguan (Yakobus 1:5-7; Markus 11:24). Doa yang disertai iman menimbulkan keyakinan bahwa apa yang kita minta itu sudah kita peroleh, sebab Allah telah mendengar doa itu serta memberikannya kepada kita. ${ }^{44}$

Berdasarkan pengertian tersebut, berdoa dengan iman berarti mempercayai firman Tuhan dan berkata ya terhadap janji-janji Tuhan serta menyerahkan diri dalam segala aspek kehidupan kita kepada Allah yang adalah sumber pemberi.

Sebagai pemimpin persekutuan maka hamba Tuhan tersebut harus benar-benar dapat membimbing karyawannya agar dapat memanjatkan doa yang benar dan penuh iman kepada Tuhan khusunya orang yang menjadi pendoa itu harus orang yang telah menerima Kristus dalam hidupnya sebagai Tuhan dan Juruselamatnya agar doanya di dengar dan dijawab oleh Tuhan.

Jadi, untuk menciptakan kehidupan rohani dalam bisnis maka harus dilakukan ibadah dan doa di tempat usaha.

Membentuk persekutuan Kristen bukan berarti bahwa karyawan yang nonKristen tidak diperhatikan tetapi kita sebagai hamba Tuhan melihat itu sebagai ladang pelayanan yang besar untuk menginjili orang-orang yang belum pernah mendengar kabar baik itu. ${ }^{45}$ Menurut Jeremie Lie, hal yang dilakukan sebagai pengusaha Kristen adalah membentuk persekutuan Kasih Misi Persaudaraan maksudnya bagaimana peranan seorang pengusaha Kristen dalam penginjilan yang seharusnya misi ini dilakukan berdasarkan kasih Allah seperti yang diungkapkan penulis sebelumnya, di mana melalui persekutuan seperti ini dapat membangun hubungan yang baik dengan karyawan atau pengusaha non-Kristen di mana misi utama dari persekutuan ini untuk membebaskan mereka dari kegelapan dosa yang mengikat dan membelenggu mereka. ${ }^{46}$

Donald B. Kraybill menjelaskan,

Dalam bahasa Yunani agape berarti kasih yang tidak bersyarat dan sering digunakan untuk mendefenisikan kasih Allah. Kasih agape yang sunnguh sama sekali tidak mementingkan diri sendiri. Ia melebihi penderitaan, persahabatan, dan kebaikan. Agape melampaui kepentingan diri sendiri. Agape adalah tindakan. Agape mengasihi mereka yang tidak patut dikasihi bahkan musuh-musuh sekalipun. Rela ikut menderita, kemurahan hati, pengampunan, belas kasihan. Semua ini adalah inti agape. ${ }^{47}$

\footnotetext{
${ }^{40}$ Kamus Besar Bahasa Indonesia, s.v. "doa”

${ }^{41}$ Harold M. Frelig, Delapan Tiang Keselamatan (Bandung: Yayasan Kalam Hidup, 1962), 85.

${ }^{42}$ Kamus Besar Bahasa Indonesia., s.v. "iman".

${ }^{43}$ Harold M. Frelig, Delapan Tiang Keselamatan (Bandung; Kalam Hidup, 1962), 26.

${ }_{45}^{44}$. Wesley Brill, Dasar yang Teguh (Bandung; Kalam Hidup, n.d.), 215

${ }^{45}$ Hendrik Gomulyo, Wawancara Oleh Penulis, Makassar, Sulawesi Selatan, 16 Mei 2010.

${ }^{46}$ Jeremie Lie, Penulisan: Peranan Seorang Pengusaha Kristen dalam Pelayanan Pekerjaan Tuhan (Makassar:
} STTJ, 2001), 42-46.

${ }^{47}$ Donald B. Kraybill, Kerajaan Yang Sungsang (Jakarta: BPK Gunung Mulia, 1993), 169. 
Sebagai hamba Tuhan yang berbisnis, kita harus mengasihi karyawan yang nonKristen karena mereka adalah ladang untuk penginjilan. ${ }^{48}$

Dalam Ensiklopedia Alkitab Masa Kini jilid 1; A-L dijelaskan orang Kristen harus mengasihi saudaranya. Orang Kristen mengasihi saudaranya karena: (1) Meneladani kasih Allah (Matius 5:43, 45; Efesus 5:2; I Yohanes 4:11); (2) Bagi dia, saudara itu adalah orang yang untuknya Kristus telah mati (Roma 14:15; I Korintus 8:11); (3) Ia melihat dalam diri saudara itu Kristus sendiri (Matius 25:40). Perilaku saling mengasihi ini, yang terwujud dalam persekutuan umat Kristen (Efesus 4:2; Filipi 2:ldst) adalah ciri khas dari realita kemuridan Kristen bagi dunia luar (Yohanes 13:15). ${ }^{49}$

Jadi, dalam lingkungan bisnis, menciptakan kegiatan rohani ini sangat penting karena dengan cara demikian maka pengelolah dan karyawan dapat memiliki hubungan yang erat dengan sang pemilik bisnis yaitu Tuhan sendiri. Sehingga kasih Allah itu ada benar-benar dapat tercermin dalam setiap pribadi yang ada dalam lingkungan bisnisnya.

\section{Menerapkan Prinsip Alkitabiah dalam Bisnis}

Hamba Tuhan yang berbisnis harus menerapkan prinsip Alkitabiah dalam bisnisnya sama halnya menerapkan fungsi dan tujuan bisnis Kristen. Menurut Myron Rush, ada beberapa prinsip Alkitabiah yang perlu diterapkan dalam bisnis, yaitu:

Pertama, mengutamakan sekaligus melibatkan Tuhan dalam setiap perencanaan pribadi maupun bisnis. Ulangan 6:5. Matius 6:33. Ada dua alasan penting untuk mengutamakan Allah dalam hidup dan bisnis kita. Pertama, Allah tidak puas menempati tempat kedua. Ia mau menjadi Tuhan atas segalanya. Dalam Keluaran 20:3, Allah tidak mau ada allah lain di hadapan-Nya, senada dengan Matius 6:24, yang menyatakan bahwa kita tidak dapat melayani dua tuan. Dengan kata lain, tidak ada apa pun dalam hidup kita yang boleh mendahului Tuhan - bukan bisnis kita, bukan uang, bukan keluarga, bukan apa pun dalam dunia ini.

Alasan kedua untuk mengutamakan Allah dalam bisnis kita ada terdapat dalam Matius 6:33, ayat ini menunjukkan bahwa bila Tuhan, menempati kedudukan pertama dalam bisnis kita, maka segala hal yang dicari-cari oleh orang-orang dunia ini akan diberikan Tuhan kepada kita sebagai bonus, sesuai dengan hal yang terbaik bagi kita.

Kedua, mempelajari dan menerapkan firman Tuhan. Merupakan hal yang penting untuk mempelajari serta menerapkan firman Tuhan karena ini merupakan pedoman hidup agar setiap karyawan bahkan hamba Tuhan sendiri tidak menyimpang dari kebenaran dan melakukan bisnis seturut kehendak Tuhan (Yosua 1:8; Maz 19:8-12).

Ketiga, mengharapkan hal-hal yang besar dari Allah yang besar ( Efesus 3:20).

Keempat, menghargai manusia melebihi barang atau benda. Seorang pengusaha haruslah menghargai karyawannya. Kasih Allah harus hadir dalam diri pengelolah bisnis agar tidak memperlakukan karyawannya dengan seenaknya. Kasih Allah artinya kasih yang berkorban tanpa menuntut balas. Mengganggap karyawan sebagai rekan sekerja bukan budak yang ia perlakukan seenaknya.

Kelima, memberi yang terbaik kepada Allah. Memberi yang dimaksudkan adalah pemberian dengan sukarela, di luar perpuluhan dan buah sulung. Konsep tentang member kepada Allah tidak dijelaskan secara harafiah dalam Alkitab tetapi yang kita jumpai adalah ajaran Tuhan tentang member kepada orang miskin. Memang secara harafiah tidak ditemui kata memberi kepada Allah tetapi seperti yang dikatakan dalam Matius 25:40 dimana Yesus berkata,"Sesungguhnya segala sesuatu yang kamu lakukan untuk salah seorang dari saudara-saudara-Ku yang paling hina ini, maka kamu telah melakukannya untuk Aku". Jadi, memberi kepada orang-orang dunia secara tidak langsung telah member kepada Allah.

Keenam, bersikap jujur dan tulus. Kejujuran sangat penting, walaupun nampaknya hal init tidak mudah. Namun bagi hamba Tuhan yang mengakui bahwa dia hanya sebagai pengelolah dan bukan pemilik akan mampu bersikap jujur karena percaya bahwa berkat itu datangnya dari Tuhan, mau untung atau rugi itu harus dapat diterima asalkan melakukannya dengan jujur dan percaya bahwa Tuhan akan mengganti berlipat kali ganda. Jadi, sebagai pengelola harus bersikap jujur karena melalui kejujuran berkat Tuhan akan berkelimpahan.

Ketujuh, rajin dalam mengejar kesuksesan. Tuhan menginginkan agar kita rajin dalam bekerja karena kuncinya jelas terletak pada orangnya, apakah ia rajin atau malas. Orang rajin adalah jaminan kelimpahan seperti yang diungkapkan dalam Amsal 21:5,"Rancangan orang rajin semata mendatangkan kelimpahan...." Orang rajin suka berimajinasi, memikirkan, dan merealisasikannya sedangkan orang malas suka melamun, membual, dan menunda-nunda. Orang rajin mengoperasionalkan imannya dengan berupaya secara konsisten dan disiplin untuk melaksanakan setiap hal hal yang telah didoakan dan direncanakannya. Berdoa sungguh-sumgguh dan bekerja sungguhsungguh. ${ }^{50}$

\footnotetext{
${ }^{48}$ Benyamin Tombe, Wawancara Oleh Penulis, Makassar, Sulawesi Selatan, 28 Mei 2010

${ }^{49}$ Ensiklopedia Alkitab Masa Kini, Jilid I: A-L (Jakarta: Yayasan Komunikasi Bina Kasih/OMF, 1992), s. v. "kasih"

${ }^{50}$ Elsan Tan, Siapa Bilang Hamba Tuhan Bukan Pengusah!, (Light Publishing, 2010, s.v.), 104.
} 
Kedelapan, hidup dalam kekudusan. Kekudusan adalah modal utama hamba Tuhan dalam menjalankan bisnisnya karena dengan hidup kudus maka hamba Tuhan tidak akan toleransi dengan dosa dan dapat menerapkan prinsip Alkitabiah.

Jadi, memenuhi kebenaran Kristus tampaknya mustahil saat diperhadapkan dengan masalah yang mengharuskan seorang hamba Tuhan harus menerapkan prinsip yang Alkitabiah dalam bisnisnya. Hamba Tuhan harus menyatakan imannya pada saat mengalami masalah dalam bisnisnya. Prinsip untuk tetap jujur harus dipertahankan. Seperti dalam firman Tuhan mengatakan Abraham dibenarkan karena imannya, bukan oleh perbuatannya. Ia memiliki iman yang teguh kepada Allah. Oleh karena itu prinsip Alkitabiah harus diterapkan dalam menjalankan bisnis dan harus berani dan yakin melangkah menurut kebenaran Tuhan dan Tuhan akan memperhitungkan hal itu sebagai kebenaran kita. (Roma 4:23-24).

\section{Memiliki Visi yang Jelas}

Seorang hamba Tuhan yang berbisnis patut memiliki visi yang jelas dan visi itu bukanlah sembarang visi yang dia tetapkan sendiri tetapi seperti halnya yang telah dijelaskan sebelumnya dalam prinsip-prinsip Alkitabiah di mana salah satu dari prinsip itu menjelaskan bahwa harus mengutamakan dan melibatkan Tuhan dalam setiap hal, demikian halnya dengan menentukan visi dalam bisnisnya haruslah melibatkan Tuhan agar visi itu benar-benar berasal cdari Tuhan. Visi adalah iman yang hidup, seperti iman yang dimiliki oleh Abraham. Abraham tetap percaya dengan visi yang Tuhan berikan walaupun belum terjadi tapi ia tetap meyakininya.

Visi dari Tuhan akan terjadi saat kita benar-benar mempercayai-Nya di saat-saat yang mungkin secara dunia tidak akan berhasil tetapi Allah tidak perna ingkar janji. Salah satu tokoh Alkitab yang berhasil karena memiliki visi dari Allah adalah Yusuf. Yusuf telah memiliki visi yang diberikan Tuhan melalui mimpi-mimpinya. Ketika dia dibuang ke dalam sumur kemudian di jual di Mesir, dia tidak kehilangan visi itu karena ia memiliki sikap hati yang kuat yang membuatnya dapat melepaskan diri dari segala pencobaan. Situasi yang buruk dihadapinya dengan hati yang positif, sehinggah situasi tersebut diubah oleh Tuhan.

Tokoh Yusuf merupakan salah satu dari tokoh Alkitab yang dapat menjadi teladan buat hamba Tuhan agar tetap pada visi yang diberikan oleh Tuhan walau apapun yang terjadi. Karena kesalehan dan kepatuhannya pada Tuhan maka Yusuf dapat menjadi orang yang berhasil pada masanya.

Jadi, visi yang ingin dicapai itu harus berasal dari Tuhan di mana dalam menuju visi maka harus ada misi yang di dalamnya ada strategi, rencana dan program. Hanya melalui hubungan yang akrab dengan Tuhan maka seorang hamba Tuhan penuh waktu dapat memahami visi yang Tuhan berikan.

\section{Memiliki dan Menerapkan hikmat Allah}

Keberhasilan atau kegagalan dari usaha itu disebabkan oleh faktor manusianya, bukan modal, manajemen atau hal-hal lainnya. Karena itu, hikmat sangat dibutuhkan. Di mana sebagai orang percaya, kita dapat meminta hikmat dari Tuhan. Hikmat Allah perlu diterapkan karena hikmat adalah kunci utama untuk memiliki segala sesuatu yang Anda butuhkan dan inginkan dalam kehidupan. ${ }^{51}$ Ini berarti bahwa keberhasilan dalam hidup akan terjadi apabila kita sungguh-sungguh menerapkan hikmat yang asalnya dari Allah.

Larry Lea mengatakan,"hikmat adalah kesanggupan yang diberikan oleh Allah untuk memahami sifat sebenarnya dri sesuatu hal dan untuk melaksanakan kehendak Allah mengenai hal itu." ${ }^{52}$ Alkitab mengatakan,"Percayalah kepada Tuhan dengan segenap hatimu, dan janganlah bersandar kepada pengertianmu sendiri. Akuilah Dia dalam segala lakumu, maka Ia akan meluruskan jalanmu"(Amsal 3:5-6). Hikmat Allah dapat kita miliki apabila kita mendekatkan diri kepada Tuhan khususnya berkomunikasi dengan Allah melalui doa.

Seorang pegelolah bisnis dapat melakukan kebenaran atau kejujuran dalam bisnisnya apabila ia menerapkan hikmat Allah dalam tempat usahanya. Hikmat Allah membantu seorang pengusaha Kristen untuk melakukan tindakan yang tepat dalam urusan bisnisnya misalnya memecat atau menerima karyawan perlu hikmat Allah, ada masalah dalam perusahaan maka untuk menyelesaikannnya dibutuhkan hikmat dari Allah. Dengan hikmat Allah maka seorang hamba Tuhan tidak akan terjerat dalam materialisme tetapi akan memberikan keuntungan yang dia peroleh untuk menyenangkan hati Tuhan.

Jadi, dengan menerapkan hikmat Allah maka akan lebih memudahkan hamba Tuhan penuh waktu untuk melaksanakan prinsip-prinsip Alkitabiah dalam bisnisnya dan melalui hikmat yang Tuhan berikan akan membantunya untuk mencapai visi. Hikmat Allah adalah kunci dari keberhasilan bisnisnya.

\footnotetext{
${ }^{51}$ Larry Lea, Hikmat (Jakarta: Yayasan Pekabaran Injil Immanuel, 1998), 7.
} 


\section{Bahaya-Bahaya Menjadi Hamba Tuhan yang Berbisnis}

Menjadi seorang hamba Tuhan penuh waktu yang memiliki usaha perlu adanya sikap waspada terhadap bahaya-bahaya yang mungkin bisa terjadi seperti:

\section{Jebakan iblis}

Hamba Tuhan yang berbisnis harus selalu memiliki sikap waspada terhadap jebakan yang diberikan oleh iblis khususnya dalam hal materialisme. Jake Barnet menjelaskan bahwa materialisme adalah penyimpangan penyediaan Allah akan dunia materi atau perhambaan terhadap hal-hal materi. Materialisme meliputi cinta uang, suatu keinginan yang tak terkendalikan akan hal-hal materi, dan dikuasai oleh hal-hal materi. ${ }^{53}$ Bukan berarti melarang orang atau pendeta untuk kaya tetapi perlu diwaspadai agar kita tidak jatuh dalam roh ketamakan. Dalam surat Ibrani 13:5 sangat jelas bagaimana kita harus waspada terhadap hal-hal materi, menjadi kaya bukanlah suatu tanda materialisme, sebaliknya kemiskinan juga bukan tanda tidak adanya materialisme ${ }^{54}$.

Dalam I Timotius 6:10, mengatakan,"karena akar dari segala kejahatan adalah cinta uang. Sebab oleh memburu uanglah beberapa orang telah menyimpang dari iman dan menyiksa dirinya dengan berbagai-bagai duka." Ayat ini dapat menjadi pegangan bagi hamba Tuhan yang berbisnis agar mereka selalu waspada, tidak serakah tetapi melalui bisnis ia memberikan penghasilan itu kepada kas gereja bukan untuk dirinya sendiri.

Dalam bab-bab sebelumnya penulis telah menjelaskan bahwa tujuan dari bisnis bagi orang percaya adalah memuliakan Allah bukan hanya mencari keuntungan. Ini dimaksudkan agar orang percaya tahu bahwa dalam berbisnis, sangatlah berbahaya mencintai uang karena dapat menjadikan orang lupa akan kebenaran firman Tuhan. Oleh karena itu, hamba Tuhan yang berbisnis perlu waspada terhadap uang jangan sampai menggunakan uang sebagai segala-galanya atas hidup ini (Lukas 16:13). Jangan sampai roh keserakahan merayap ke dalam urusan bisnis yang sedang dijalankan.

Richard J. Foster. Mengemukakan bahwa bisnis adalah sisi sosial dari uang. ${ }^{55}$ Menggunakan uang untuk menunjang pelayanan. Perlu juga kita mengubah paradigma pemikiran kita tentang kepemilikan, kita harus menyadari bahwa bumi adalah milik Allah, itu berarti bisnis pun adalah milik Allah. Karena ini semua adalah milik Allah maka kita harus menggunakannya untuk kemuliaan Tuhan. ${ }^{56}$ Tuhan adalah penguasa segala dunia usaha, yang terpenting adalah ketaatan dan pemuliaan Tuhan dalam kehidupan berbisnis sehingga melalui pekerjaan kita mendapat bagian dari anugerah Tuhan. Hamba Tuhan haruslah mencontohi teladan Rasul Paulus yang mau menerima kedaan hidupnya, termasuk dalam hal keuangan. Paulus mengesampingkan hak-haknya dibidang keuangan dan bekerja membuat kemah untuk memenuhi kebutuhannya sendiri Filipi 4:11-12.

Jadi, sebagai hamba Tuhan yang memiliki bisnis patut berhati-hati dan tetap berpedoman firman Tuhana agar ia tidak terjerat dalam tipu daya iblis. Harus menyadari bahwa ia adalah pengelola dan bukan pemilik sehingga keberhasilan atau keuntungan yang ia dapat itu digunakan untuk kemuliaan Tuhan bukan untuk keegoisan atau ketamakannya sebagai manusia yang ingin memuaskan keinginan dirinya.

\section{Lari dari Panggilan}

Bahaya kedua yang dapat terjadi pada seorang hamba Tuhan yang berbisnis adalah lari dari tugas panggilannya sebagai hamba Tuhan. Bisnis yang dulu dianggap sebagai pekerjaan sampingan kini membuat ia lupa akan tugasnya sebagai dan menjadikan bisnis sebagai yang utama dalam hidupnya. Ini dapat membuatnya menjadi batu sandungan bagi pelayananya.

Tokoh Yunus dalam Alkitab mengingatkan setiap hamba Tuhan untuk tidak melarikan diri dari panggilannya. Allah menegurnya dengan jalan memsukkannya ke dalam perut ikan besar tiga hari tiga malam sampai dia mau kembali untuk melaksanakan panggilan Tuhan. Kisah Yunus menghimbau setiap hamba Tuhan untuk tidak lari dari panggilannya dan memprioritaskan pelayanan.

Jadi, setiap hamba Tuhan penuh waktu harus berhati-hati dalam menjalankan bisnis jangan sampai bisnis membuatnya melarikan diri dari tugas dan tanggung jawab utamanya yaitu pelayanan. Ia harus setia dan percaya bahwa usahanya pasti diberkati Allah asalkan ia tetap setia pada tugas utamanya karena berkat itu bersumber dari Allah. 1987), 116-118.

${ }^{53}$ Jake Barnet, Harta dan Hikmat: Pandangan Alkitab tentang Kekayaan (Bandung: Yayasan Kalam Hidup,

\footnotetext{
${ }^{54}$ Ibid, 118

${ }^{55}$ Richard J. Foster, Uang, Seks, dan Kekuasaan (Bandung: Yayasan Kalam Hidup, 1985), 64

${ }^{56}$ Ibid, $37-38$.
} 


\section{PENUTUP}

Pada bagian akhir dari penulisan karya ilmiah ini, penulis akan memberikan kesimpulan dan saran yang berkaitan dengan pokok bahasan yang telah diuraikan dalam tulisan ini. Ada pun pembahasanya adalah sebagai berikut:

\section{Kesimpulan}

Pertama, bisnis merupakan suatu kegiatan menyalurkan jasa dari produsen kepada konsumen untuk menghasilkan keuntungan yang dipakai untuk kemuliaan Allah. Di mana dalam bisnis seorang hamba Tuhan penuh waktu haruslah memperhatikan tujuan bisnis, fungsi bisnis, etika bisnis, sasaran bisnis sesuai dengan ajaran ke-Kristenan karena bisnis adalah milik Allah.

Kedua, bisnis bukan hal yang kotor dan tidak ada larangan dalam Alkitab bahwa seorang hamba Tuhan penuh waktu boleh berbisnis sebaliknya firman Tuhan banyak mengajarkan bagaimana seharusnya melakukan bisnis dengan benar. Walaupun tidak ada larangan tetapi seorang hamba Tuhan harus memiliki prinsip yaitu jika jemaatnya mampu untuk mencukupi kebutuhan hidupnya maka ia harus fokus untuk pelayanan saja seperti halnya pelayanan yang dilakukan oleh kaum Lewi pada masa Perjanjian Lama tetapi jika jemaat tidak mampu untuk mencukupi kebutuhan hamba Tuhan maka tidak salah jika mereka melakukan bisnis.

Ketiga, walaupun tidak ada salahnya hamba Tuhan untuk berbisnis namun tidak semua aliran gerja menyetujui hamba Tuhan untuk berbisnis. Ini semua tergantung aturan tata gereja masing-masing, jika tata gereja mengizinkan hamba Tuhan boleh berbisnis maka itu boleh dilakukan asalkan tidak menjadi batu sandungan bagi jemaatnya.

Keempat, hamba Tuhan penuh waktu yang berbisnis harus dapat menyeimbangkan antara pelayanan dan bisnis karena keduanya adalah tanggung jawab kepada Tuhan.

Kelima, bisnis membuka peluang bagi hamba Tuhan untuk melakukan kegiatan rohani bersama dengan karyawannya. Kegiatan tersebut anatara lain: (1) Membentuk persekutuan Kristen. Melalui persekutuan seperti ini dapat membuat iman anak-anak Tuhan dalam lingkungan bisnis dapat bertumbuh dan dewasa secara rohani. Persekutuan itu dapat berupa ibadah bersama atau doa bersama; (2) Membentuk persekutuan kasih misi persaudaraan. Persekutuan ini diperuntukkan bagi karyawan yang non-Kristen. Melalui persekutuan seperti ini, hamba Tuhan penuh waktu dapat menunjukkan bagaimana kasih Allah itu yang berlaku bagi mereka dan misi utama dari persekutuan ini adalah membebaskan mereka dari dosa.

Keenam, hamba Tuhan yang berbisnis perlu waspada terhadap tipu daya iblis yang ingin menjatuhkannya khususnya hal materialisme. Oleh karena itu, hamba Tuhan tidak boleh serakah dan harus bersandar pada pengertian yang benar sesuai kebenaran firman Tuhan.

Ketujuh, setiap hamba Tuhan penuh waktu yang berbisnis harus memiliki dan menerapkan hikmat Allah dalam bisnisnya karena hikmat merupakan kunci keberhasilan seseorang dan melalui hikmat dari Tuhan setiap masalah dalam bisnis itu akan memiliki solusi yang tepat. Melalui hikmat Allah maka dalam bisnisnya pasti akan menerapkan prinsip-prinsip kebenaran Firman Tuhan dan visi yang akan dicapai akan bersumber dari Tuhan.

\section{Saran-Saran} berikut:

Berdasarkan kesimpulan di atas, maka penulis memberikan saran-saran sebagai

Pertama, jemaat seharusnya memperhatikan kebutuhan hamba Tuhan penuh waktu agar mereka dapat fokus dalam menjalankan tugas dan tanggung jawabnya tanpa dibebani dengan kebutuhan hidupnya.

Kedua, jemaat yang memiliki hamba Tuhan yang berbisnis harus mengerti dengan profesi hamba Tuhan tersebut dan dapat mendukung mereka bukan menganggap bisnis itu kotor atau menjadi batu sandungan bagi pelayanan hamba Tuhan tersebut.

Ketiga, hamba Tuhan atau jemaat yang memiliki bisnis harus dapat menjadikan bisnis sebagai ladang pelayanan untuk penginjilan agar banyak jiwa yang dapat dimenangkan untuk Kristus dan mereka terlepas dari belenggu dosa.

Keempat, hamba Tuhan yang berbisnis harus dapat melihat dan menempatkan bisnis sebagai milik Tuhan yang harus dijalankan sesuai kebenaran Alkitab. 


\section{KEPUSTAKAAN}

\section{Alkitab}

Alkitab. Jakarta: Lembaga Alkitab Indonesia, 2000.

\section{Kamus}

Packer, J.L, dkk. Ensiklopedia Fakta Alkitab: Bible Almanac-1. Malang: Yayasan Gandum Mas, n.d. 1992. Ensiklopedia Alkitab Masa Kini. Jakarta: Yayasan Komunikasi Bina Kasih, Ensiklopedia Perjanjian Baru. Yogyakarta: Kanisius, 1990.

Ensiklopedia Nasional Indonesia, Jilid 5. Jakarta: PT. Cipta Abadi Pustaka, 1989.

Tim Penyusun Kamus Pusat Bahasa Departemen Pendidikan Nasional. Kamus Besar Bahasa Indonesia. Jakarta: Balai Pustaka, 2001.

\section{Buku-Buku}

Anorga, Panji dan Soegiastuti, Janti. Pengantar Bisnis Modern: Kajian Dasar Manajemen Perusahaan. Jakarta: Dunia Pustaka Jaya, 1996.

Bernet, Jake. Harta dan Hikmat. Bandung: Yayasan Kalam Hidup, 1987.

Bertens, K. Etika. Jakarta. PT Gramedia Pustaka Utama, 1994.

Brill, J. Wesley. Dasar yang Teguh. Bandung: Kalam Hidup, n.d.

Burkett, Larry. Kunci Sukses Bisnis Menurut Alkitab. Yogyakarta: Yayasan Andi, 1997.

Dixon, R. Tafsiran Kisah Para Rasul. Malang: Gandum Mas, 2005.

Freligh, Harold M. Delapan Tiang Keselamatan. Surabaya: Bethany Fellowship, 1962.

Goenen OFM. C. Pengantar ke dalam Perjanjian Baru. Yogyakarta: Kanisius, 1984.

Hocking, David. Rahasia Keberhasilan Seorang Pemimpin. Yogyakarta: Yayasan Andi, 1997.

Keraf, Sonny A. Mengatur Keuangan dengan Bijak. Bandung: Yayasan Kalam Hidup, 1985.

Kraybill, Donald B. Kerajaan yang Sungsang. Jakarta: BPK Gunung Mulia, 1993.

Lasor, W.S. Pengantar Perjanjian Lama 1: Taurat dan Sejarah. Jakarta: BPK Gunung Mulia, 1993

Lea, Larry. Hikmat: Janganlah Menghayati Hidup Tanpa Hikmat. Jakarta: Yayasan Pekabaran Injil Immanuel, 1991.

Njotorahardjo, Niko dan Santoso, Iman. Transformation Journey. Yogyakarta: Penerbit Andi, 2007.

Richard, Foster J. Uang, Seks, dan Kekuasaan. Bandung: Kalam Hidup, 1985.

Sembiring, Mahli. Kiat Bisnis Kristen. Jakarta: Pustaka Sinar Harapan, 1997.

Solihin, Ismail. Pengantar Bisnis: Pengenalan Praktis dan Studi Kasus. Jakarta: Prenada Media Group, 2006.

Tan, Elsen. Siapa Bilang pengusaha Bukan Hamba Tuhan!. Light Publishing, 2010. s.v.

Tenney, Merril C. Survei Perjanjian Baru. Malang: Gandum Mas, 1993

Tobing, Tumbur. Manusia Sejati Manusia Sukses. Bandung: Yayasan Kalam Hidup, 2009.

Verkuyl, J. Etika Kristen Bagian Umum. Jilid 1. Jakarta: BPK Gunung Mulia, 1985.

White, Jerry dan Mary. Bekerja. Jakarta: BPK Gunung Mulia, 1980.

Wiguna, Donny A. Tafsir Roma Bagi Pekerja. Yogyakarta: Yayasan Andi, 2008.

Wursanto, Ig. Etika Komunikasi Kantor. Yogyakarta: Kanisius, 1984. 